\title{
Impacts of snow and glaciers over Tibetan Plateau on Holocene climate change: Sensitivity experiments with a coupled model of intermediate complexity
}

\author{
Liya Jin, ${ }^{1}$ Andrey Ganopolski, ${ }^{2}$ Fahu Chen, ${ }^{1}$ Martin Claussen, ${ }^{2}$ and Huijun Wang ${ }^{3}$ \\ Received 15 April 2005; revised 10 July 2005; accepted 18 August 2005; published 15 September 2005.
}

[1] An Earth system model of intermediate complexity has been used to investigate the sensitivity of simulated global climate to gradually increased snow and glacier cover over the Tibetan Plateau for the last 9000 years $(9 \mathrm{kyr})$. The simulations show that in the mid-Holocene at about $6 \mathrm{kyr}$ before present (BP) the imposed ice sheets over the Tibetan Plateau induces summer precipitation decreases strongly in North Africa and South Asia, and increases in Southeast Asia. The response of vegetation cover to the imposed ice sheets over the Tibetan Plateau is not synchronous in South Asia and in North Africa, showing an earlier and, hence, a more rapid decrease in vegetation cover in North Africa from 9 to $6 \mathrm{kyr} \mathrm{BP}$ while it has almost no influence on that in south Asia until 5 kyr BP. The simulation results suggest that the snow and glacier environment over the Tibetan Plateau is an important factor for Holocene climate variability in North Africa, South Asia and Southeast Asia. Citation: Jin, L., A. Ganopolski, F. Chen, M. Claussen, and H. Wang (2005), Impacts of snow and glaciers over Tibetan Plateau on Holocene climate change: Sensitivity experiments with a coupled model of intermediate complexity, Geophys. Res. Lett., 32, L17709, doi:10.1029/2005GL023202.

\section{Introduction}

[2] Studies on globally distributed multi-proxy palaeoclimate data revealed that Holocene climate was more variable than previously believed. It is suggested that changes in insolation related both to Earth's orbital variations and to solar variability played a central role in the global scale changes in climate of the last 11.5 cal kyr [Mayewski et al., 2004]. This insolation driving mechanism in the Holocene climate change is supported by climate modeling experiments of the variation of tropical monsoon climate in North Africa and South Asia [Kutzbach and Guetter, 1986; COHMAP Members, 1988] and of changes in the African-Asian monsoon precipitation [Weber et al., 2004]. However, external forcing, e.g., the Earth's orbital variations and the solar variability, can be amplified and modified through a number of feedbacks within the climate system leading to marked climate variations in the Holocene [Foley et al., 1994; TEMPO Members, 1996; Claussen and

\footnotetext{
${ }^{1}$ National Laboratory of Western China's Environmental Systems, Center for Arid Environment and Paleoclimate Research, Lanzhou University, Lanzhou, China.

${ }^{2}$ Potsdam Institute for Climate Impact Research, Potsdam, Germany.

${ }^{3}$ Institute of Atmospheric Physics, Chinese Academy of Sciences, Beijing, China.
}

Copyright 2005 by the American Geophysical Union. 0094-8276/05/2005GL023202\$05.00
Gayler, 1997; Ganopolski et al., 1998b; Wang, 1999]. The atmosphere-vegetation feedback is an important amplifying factor of the North Africa's abrupt climate transition from a wet phase to a dry phase starting at around $6 \mathrm{kyr}$ BP [Claussen et al., 1999]. Studies from lake sediment pollen and carbonate records showed the arid phase in South Asia probably started around 5 kyr BP [Maxwell, 2001; Singh, 2002], coinciding with a stepwise weakening of the southwest monsoon [Gupta and Anderson, 2005], which was closely linked to North Atlantic cold spells, e.g., the millennial-scale cold events during 4.6-4.2 kyr BP [Gupta et al., 2003]. In addition, it is indicated that the Holocene optimum, as defined by peak precipitation or effective moisture, is asynchronous in eastern Asian monsoon regions, which is related to a general weakening and southward retreat of the East Asian summer monsoon since about 9 kyr B.P. [An et al., 2000].

[3] As one of the most imposing topographic features in Central Asia, with a mean elevation of $\sim 4.5 \mathrm{~km}$ above sea level and an area of $2.5 \times 10^{6} \mathrm{~km}^{2}$, the Tibetan Plateau plays a significant role in global climate change [Yanai et al., 1992]. Earlier study of glacier changes has revealed that there were intervals of glacier advances over the Tibetan Plateau during the Holocene at about 8.2-7.2kyr BP, 5.8$4.9 \mathrm{kyr} \mathrm{BP}, 3 \mathrm{ky} \mathrm{BP}$ and $300-450 \mathrm{yr} \mathrm{BP}$, respectively [Lehmkuhl, 1997]. Newer observation from the Guliya ice cap which is located in northwest region of the Tibetan Plateau and whose records is believed to cover more than 100,000 years, spanning the whole Holocene to the last interglacial [Christner et al., 2003] showed a rapid decrease in temperature up to $3 \sim 4^{\circ} \mathrm{C}$ during the period of $7-5 \mathrm{kyr}$ BP [Thompson et al., 1997; Yao et al., 2000]. Recently, by using a set of data from a fully coupled ocean-atmosphere model (FOAM), Casal et al. [2004] calculated the ice-sheet mass balance for the Tibetan Plateau for the present day, and for the past simulations, under the insolation forcings at 3 kyr BP, 6 kyr BP, 8 kyr BP and 11 kyr BP. The result shows that the area with positive ice-sheet mass balance expands from $11 \mathrm{kyr}$ BP to $0 \mathrm{kyr}$ BP [Casal et al., 2004, Figure 11]. This modeling result is potentially consistent with some observations, especially the observed development of the Dasuopu ice sheets (located in the southwestern region of the Tibetan Plateau) in the Holocene [Thompson et al., 2000].

[4] Climate studies for the present day have shown that the sensible heat flux and latent heat flux released over the Tibetan Plateau has a close relationship with Asian summer monsoon and strongly influence global circulation patterns [e.g., Yanai et al., 1992], whereas the growth and wasting of snow and glaciers are directly related to heat fluxes over the Tibetan Plateau. Here we argue that the glacier advances 

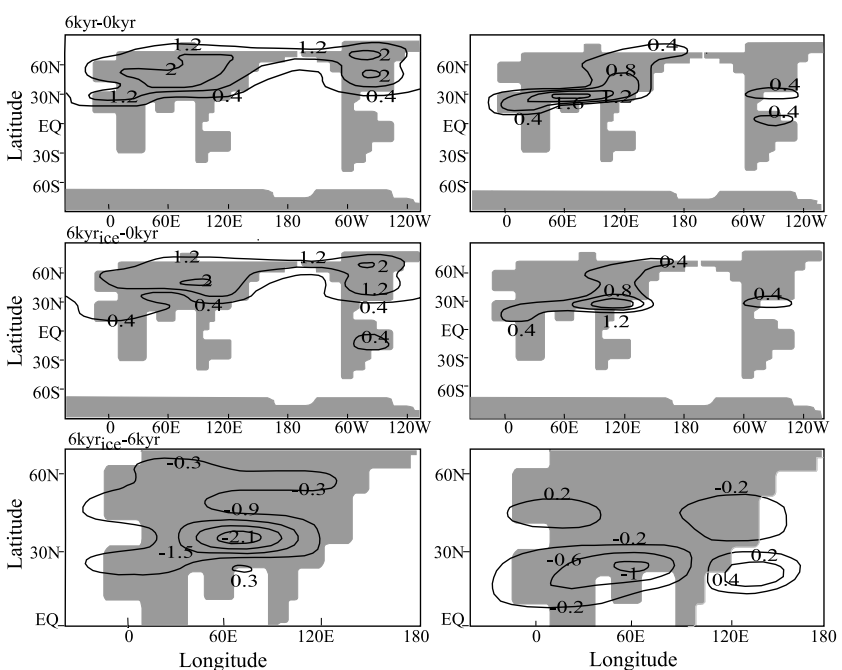

Figure 1. (left) Near-surface air temperatures (in ${ }^{\circ} \mathrm{C}$ ) and (right) precipitation (in $\mathrm{mm} /$ day) during boreal summer (0 kyr for present day, $6 \mathrm{kyr}$ for mid-Holocene and $6 \mathrm{kyr}_{\text {ice }}$ for mid-Holocene with ice cover over the Tibetan Plateau).

over high Asia was probably one of the amplifying factors for the retreat of African-Asian monsoon, and hence leading to climatic changes in areas highly influenced by AfricanAsian monsoon systems during the Holocene.

[5] In an attempt to explore the impacts of snow and glaciers over the Tibetan Plateau on Holocene climate change, we conduct a series of sensitivity experiments by using an Earth system model of intermediate complexity, CLIMBER-2. The model encompasses a 2.5-dimensional dynamical-statistical atmosphere model, a multibasin, zonally averaged ocean model including sea ice, and a dynamic model of terrestrial vegetation [Petoukhov et al., 2000]. CLIMBER-2 has a coarse but geographically explicit resolution. In the model, vegetation cover is represented as a mixture of trees, grass, and desert (bare soil). The fraction of each is not a discrete, but a continuous function of growing degree-days (sum of mean daily temperature for days with temperature above $0^{\circ} \mathrm{C}$ ) and annual precipitation. Hence, CLIMBER-2 is able to describe changes in vegetation cover that can be interpreted as shifts in vegetation zones smaller than the spatial resolution of the model. The CLIMBER-2 model has been validated against present-day climate and general circulation models (GCMs) simulations [Petoukhov et al., 2000; Ganopolski et al., 2001] and has been used successfully for a variety of paleoclimate studies [Ganopolski et al., 1998a; Claussen et al., 1999].

\section{Modeling Experiment Setup}

[6] Two types of experimental setup are employed for the present studies. One is the $6 \mathrm{kyr} \mathrm{BP}$ slice run with prescribed fractional snow and glacier cover in the grid cell containing the Tibetan Plateau (Figure 1), to mimic a cooling effect of rapid decrease in temperature at the midHolocene (during 7-5 kyr BP) over the Tibetan Plateau, as shown in the Guliya ice core by Thompson et al. [1997]. The other is the transient run with various scenarios of linear increase of the snow and glacier fraction over the Tibetan Plateau for the past 9 kyr (Figure 2a), to mimic a gradually expansion of ice sheet mass balance areas over the Tibetan Plateau during the Holocene, based on the FOAM results [Casal et al., 2004]. Although the prescribed linear evolution of the snow and glacier changes for the Holocene may not be the case as it were, it can be as a preliminary study for testing the effect of gradually expansion of the positive ice-sheet mass balance areas over the Tibetan Plateau on Holocene climatic change.

[7] The simulation experiments are set up as follow: First, a control run was performed, using the fully coupled atmosphere-ocean-vegetation configuration of the model for preindustrial climate conditions (when the system was close to equilibrium); that is, modern solar insolation and a $\mathrm{CO}_{2}$ concentration of $280 \mathrm{ppm}$. To attain equilibrium, the control simulation was integrated for 3000 years. Second, we performed two simulations for the mid-Holocene using different model configurations. As by Ganopolski et al.
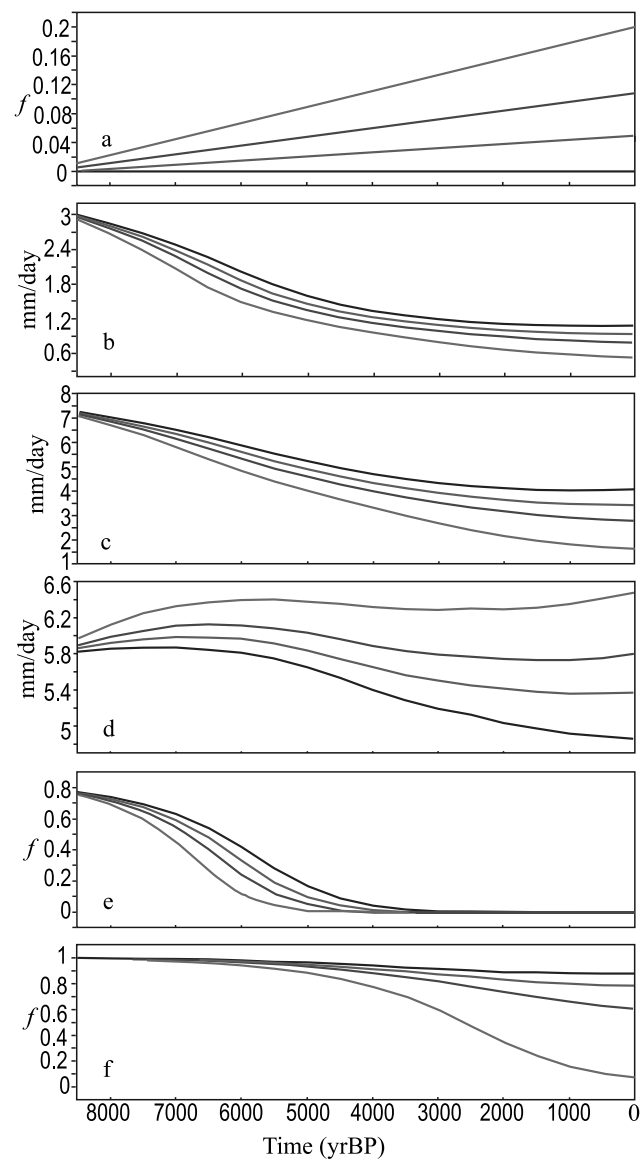

Figure 2. (a) Linear variation of fraction $f$ of ice sheets over the Tibetan Plateau in the transient simulation. (b) Summer (June, July, August) precipitation on average over North Africa $\left(15^{\circ} \mathrm{W}-40^{\circ} \mathrm{E}, 20^{\circ} \mathrm{N}-30^{\circ} \mathrm{N}\right)$ simulated for the last 9 kyr; (c) Same as Figure $2 \mathrm{~b}$ but for South Asia $\left(40^{\circ} \mathrm{E}-95^{\circ} \mathrm{E}, 20^{\circ} \mathrm{N}-30^{\circ} \mathrm{N}\right)$; (d) Same as Figure $2 \mathrm{~b}$ but for Southeast Asia $\left(95^{\circ} \mathrm{E}-145^{\circ} \mathrm{E}, 20^{\circ} \mathrm{N}-30^{\circ} \mathrm{N}\right)$. (e) Same as Figure $2 \mathrm{~b}$ except for the fraction $f$ of vegetation cover. (f) Same as Figure 2e except for regions over South Asia. Colors indicate the maximum fraction $f$ of ice cover over the Tibetan Plateau at the end of the simulation, with 0 (blue), 0.05 (green), 0.1 (red), and 0.2 (grey), respectively. See color version of this figure in the HTML. 
[1998b], orbital parameters were set to mid-Holocene (6 kyr BP) values [Berger, 1978], resulting in an enhanced seasonal cycle of solar insolation in the northern hemisphere. The atmospheric $\mathrm{CO}_{2}$ concentration was the same as in the control run. Experiment A1 employed the fully coupled atmosphere-ocean-vegetation model as in the control run, and Experiment A2 was the same as Experiment A1 but with a fraction of ice in the grid cell to get the effect of a rapid decrease in temperature corresponding to the Tibetan Plateau $\left(30-40^{\circ} \mathrm{N}, 40-90^{\circ} \mathrm{E}\right)$ in the model. Third, a set of transient simulations for the last $9 \mathrm{kyr}$ was performed. In the first of transient experiments (B1) CLIMBER-2 was run from an equilibrium state corresponding to permanent orbital forcing at $9 \mathrm{kyr}$ BP for $9 \mathrm{kyr}$ until the present driven only by changes in orbital parameters, as by Claussen et al. [1999]. We also performed three additional transient experiments (B2, B3, B4) similar to experiment B1 but with prescribed linearly increasing fraction of ice sheet cover over the Tibetan Plateau, starting with 0 at $9 \mathrm{kyr} \mathrm{BP}$ and ending with 0.05 (B2), 0.1 (B3) and 0.2 (B4) at 0 kyr BP, respectively. No flux corrections between the atmospheric and oceanic modules are applied in the model in any simulation.

\section{Results}

\subsection{Temperature and Precipitation Changes in the} Mid-Holocene (6 kyr BP)

[8] The results of experiment A1 revealed pronounced responses of CLIMBER-2 to changes in orbital parameters. Simulated summer temperature is up to $2^{\circ} \mathrm{C}$ higher than at present in the northern parts of Europe, Asia, and North America, and summer precipitation is greater than today's in North Africa and South Asia, with maximum exceeding $1.6 \mathrm{~mm} /$ day at the center (Figure 1). These results are almost the same as those from an earlier version of CLIMBER-2, in patterns as well as in amplitudes of boreal near-surface air temperature and precipitation distribution [see Ganopolski et al., 1998b, Figures 2b and 2d]. When snow and glaciers are imposed over the Tibetan Plateau (Experiment A2), a cooling of exceeding $2.1^{\circ} \mathrm{C}$ in summer air surface temperature appears over the High Asia compared to experiment A1. The patterns of summer precipitation change greatly, with a pronounced decrease at maximum by $1 \mathrm{~mm} /$ day in South Asia and an increase at maximum by $0.4 \mathrm{~mm} /$ day in Southeast Asia as compared to experiment A1 (Figure 1). This tendency for the pattern of decreased precipitation in North Africa and South Asia and that increased in Southeast Asia may reflect the tendency for the weakened AfricanAsian monsoon circulation to shift the locus of monsoon rains southeastward, as a result of the thermal-driving monsoon circulation to be adjusted to adapt to the changes of thermal contrast between the African and Eurasian continent and the Pacific and Indian oceans during the boreal summer. The intensification of northern hemisphere summer monsoon in North Africa, South Asia, and East Asia in experiment A1 is the result of responding to the enhanced seasonal cycle of solar insolation in the northern hemisphere in the mid-Holocene. However, cooling over the High Asia resulted from imposed ice sheets leads to a strong positive SLP anomaly (figure not shown) located over the Tibetan Plateau in summer. This weakens the low-pressure system on the African-Asian continents, and African and
East Asian monsoon in summer. In addition, the subtropical high pressure over the western Pacific weakens and shifts southeastward. Finally, it leads to reduced precipitation from Saharan North Africa to the Middle East, north India and northeast China, but increased precipitation in Southeast Asia.

\subsection{Transient Changes in the Last 9 kyr}

[9] Figure 2b illustrates that during 8-5.5 kyr BP, a marked decrease in summer precipitation appears over North Africa, the faster the fraction of ice cover increases over the Tibetan Plateau (Figure 2a), the earlier and more greatly the precipitation changes. The strongest decrease in summer precipitation in "no-ice" run (experiment B1) appears around 5.5-6.5 kyr BP, while in the 0.05-, 0.1and 0.2 -ice scenarios, it occurs around 5.5-7, 6-7, and 6.5-7.5 kyr BP (experiments B2, B3, and B4) respectively. In south Asia, including the southern part of the Tibetan Plateau, the continual increasing ice sheets leads to a rapid and strong reduction in summer precipitation (Figure 2c), which may be attributed to the large-scale weakened summer monsoon in this region. In Southeast Asia (Figure 2d), a strong increase in summer precipitation appears associated with southeastward shifts of the subtropical high pressure over the western Pacific. Compared to the changes in precipitation, the fraction $f$ of vegetation cover changed differently. In North Africa, the faster the ice cover increases over the Tibetan Plateau, the earlier and more rapidly the decrease in vegetation cover appears (Figure 2e). In South Asia, however, the response of the changes in vegetation cover to the gradually increased ice sheets over the Tibetan Plateau lags behind North Africa a few thousand years (the fraction of vegetation cover in South Asia, reduces only $10 \%(\Delta \mathrm{f} \sim-0.1)$ for the first $5 \mathrm{kyr}$, then decreases rather abruptly ( $\Delta \mathrm{f} \sim-0.35$ ) from 3.5 to $2 \mathrm{kyr}$ BP, Figure $2 \mathrm{f})$.

\section{Summary and Concluding Remarks}

[10] In summary, the sensitivity experiments suggest that the snow and glacier environment over the Tibetan Plateau can be an important factor for Holocene climate variability in North Africa, South Asia and Southeast Asia. In North Africa, an earlier and, hence, a more rapid decrease in precipitation and vegetation was induced with a faster increase of ice sheets over the Tibetan Plateau. In South Asia, summer precipitation reduced strongly in northern Arabian Sea and Arabian Peninsula while in southeastern Asia it increased dramatically at $6 \mathrm{kyr}$ BP when snow and glaciers were imposed over the Tibetan Plateau. The evolution of the summer precipitation in North Africa and South Asia and southeastern Asia responding to the gradually increased snow and glaciers over the Tibetan Plateau seemingly corresponds to weakened eastward and southward shifts of the African-Asian summer monsoon system resulting from the reduced temperature contrast between the Eurasian continent and the Pacific and Indian oceans. The timing of rapid reduction in vegetation cover correspondence to relatively slower increase in ice sheets over the Tibetan Plateau is not synchronous in south Asia and in North Africa.

[11] Although this modeling experiment has focused on cooling effect induced by increased fraction of snow and glaciers over the Tibetan Plateau on African and Asian 
summer monsoon systems, it is also apparent that there are other factors that can amplify and/or modify the insolationonly forced monsoon response through a number of feedbacks within the climate system leading to marked climate variations during the Holocene, such as the effects of the vegetation and oceanic feedbacks. Further experiments with non-linear variation of snow and glacier cover are necessary to more precisely quantify the contribution of the snow and glacier effect over the Tibetan Plateau versus vegetation and oceanic feedbacks as well as the changes in atmospheric $\mathrm{CO}_{2}$ concentration to the Holocene African and Asian monsoon change.

[12] Acknowledgments. Jin L. is grateful to German Academic Exchange Service (DAAD) and China Scholarship Council (CSC) for providing him a scholarship during his visiting at Potsdam Institute for Climate Impact Research (PIK) in September 2003 to January 2004 E. Bauer, C. Kubatzki, R. Calov and V. Brovkin at PIK, are thanked for their helpful remarks for this research. The authors acknowledge the thoughtful comments and critique of two anonymous reviewers. This research was supported by China International Collaboration Project (2002CB714004)

\section{References}

An, Z. S., S. C. Porter, J. E. Kutzbach, X. H. Wu, S. M. Wang, X. D. Liu, X. Q. Li, and W. J. Zhou (2000), Asynchronous Holocene optimum of the East Asian monsoon, Quat. Sci. Rev., 19, 743-762.

Berger, A. (1978), Long-term variations of daily insolation and quaternary climatic changes, J. Atmos. Sci., 35, 2362-2367.

Casal, T. G. D., J. E. Kutzbach, and L. G. Thompson (2004), Present and past ice-sheet mass balance simulations for Greenland and the Tibetan Plateau, Clim. Dyn., 23, 407-425.

Christner, B. C., E. Mosley-Thompson, L. G. Thompson, and J. N. Reeve (2003), Bacterial recovery from ancient glacier ice, Environ Microbiol, 5 , $433-436$.

Claussen, M., and V. Gayler (1997), The greening of Sahara during the midHolocene: Results of an interactive atmosphere-biome model, Global Ecol. Biogeogr. Lett, 6, 369-377.

Claussen, M., C. Kubatzki, V. Brovkin, A. Ganopolski, P. Hoelzmann, and H. J. Pachur (1999), Simulation of an abrupt change in Saharan vegetation in the mid-Holocene, Geophys. Res. Lett., 26, 2037-2040.

COHMAP Members (1988), Climatic changes of the last 18,000 years: Observations and model simulation, Science, 241, 1043-1052.

Foley, J., J. E. Kutzbach, M. T. Coe, and S. Levis (1994), Feedbacks between climate and boreal forests during the Holocene epoch, Nature, $371,52-54$.

Ganopolski, A., S. Rahmstorf, V. Petoukhov, and M. Claussen (1998a), Simulation of modern and glacial climates with a coupled model of intermediate complexity, Nature, 391, 351-356.

Ganopolski, A., C. Kubatzki, M. Claussen, V. Brovkin, and V. Petoukhov (1998b), The influence of vegetation-atmosphere-ocean interaction on climate during the mid-Holocene, Science, 280, 1916-1919.

Ganopolski, A., V. Petoukhov, S. Rahmstorf, V. Brovkin, M. Claussen, A. Eliseev, and C. Kubatzki (2001), CLIMBER-2: A climate system model of intermediate complexity. part II: Model sensitivity, Clim. Dyn., 17, 735-751

Gupta, A. K., and D. M. Anderson (2005), Mysteries of the Indian Ocean monsoon system, J. Geol. Soc. India, 65, 54-60.

Gupta, A. K., D. M. Anderson, and J. T. Overpeck (2003), Abrupt changes in the Asian southwest monsoon during the Holocene and their links to the North Atlantic Ocean, Nature, 421, 354-357.

Kutzbach, J. E., and P. J. Guetter (1986), The influence of changing orbital parameters and surface boundary conditions on climate simulation for the past 18,000 years, J. Atmos. Sci., 43, 1726-1759.

Lehmkuhl, F. (1997), Late Pleistocene, late-glacial and Holocene glacier advances on the Tibetan Plateau, Quat. Int., 38-39, 77-83.

Maxwell, A. L. (2001), Holocene changes inferred from lake sediments pollen and carbonate records, northeastern Cambodia, Quat. Res., 56, $390-400$.

Mayewski, P. A., et al. (2004), Holocene climate variability, Quat. Res., 62, $243-255$

Petoukhov, V., A. Ganopolski, V. Brovkin, M. Claussen, A. Eliseev, C. Kubatzki, and S. Rahmstorf (2000), CLIMBER-2: A climate system model of intermediate complexity. part I: Model description and performance for present climate, Clim. Dyn., 16, 1-17.

Singh, I. B. (2002), Late Quaternary evolution of Ganga Plain and proxy records of climate change, neotectonics and anthropogenic activity, Pragdhara, 12, 1-25

TEMPO Members (1996), Potential role of vegetation feedback in the climate sensitivity of high-latitude regions: A case study at 6000 years B. P., Global Biogeochem. Cycles, 10, 727-736.

Thompson, L. G., T. Yao, M. E. Davis, K. A. Henderson, E. MosleyThompson, P. N. Lin, J. Beer, H. A. Synal, J. Cole-Dai, and J. F. Bolzan (1997), Tropical climate instability: The last glacial cycle from a QinghaiTibetan ice core, Science, 276, 1821-1825.

Thompson, L. G., E. Mosley-Thompson, M. E. Davis, K. A. Henderson, and P. N. Lin (2000), A high-resolution millennial record of the south Asian monsoon from Himalayan ice cores, Science, 289, 19161919.

Wang, H. J. (1999), Role of vegetation and soil in the Holocene megathermal climate over China, J. Geophys. Res., 104, 9361-9367.

Weber, S. L., T. J. Crowley, and G. van der Schrier (2004), Solar irradiance forcing of centennial climate variability during the Holocene, Clim. Dyn., $22,539-553$

Yanai, M., C. Li, and Z. Song (1992), Seasonal heating of the Tibetan Plateau and its effects on the evolution of the summer monsoon, J. Meteorol. Soc. Jpn., 70, 319-351.

Yao, T. D., X. D. Liu, and N. L. Wang (2000), On amplitudes of climatic variation in Qinghai-Tibetan Plateau (in Chinese), Chin. Sci. Bull., 45, $98-106$.

F. Chen and L. Jin, National Laboratory of Western China's Environmental Systems, Center for Arid Environment and Paleoclimate Research, Lanzhou University, Tianshui South Road No. 222, Lanzhou 730000 , China. (jinly@1zu.edu.cn)

M. Claussen and A. Ganopolski, Potsdam Institute for Climate Impact Research, P. O. Box 601203, D-14412 Potsdam, Germany.

H. Wang, Institute of Atmospheric Physics, Chinese Academy of Sciences, Beijing 100029, China. 